w zupelności wyjątkowej tej postaci pośród onomastyków krakowskich oraz jego własnego wkładu w dzieje polskiej onomastyki ${ }^{24}$.

Dlatego z całym przekonaniem o zasiugach ks. A. Klawka dla onomastyki biblijnej śmiem postulować konieczność przedruku prac onomastyeznych ks. Klawka i to nie tylko w języku polskim. Może w ramach dzieł wszystkich, a w każdym razie obok antologii jego tłumaczeń biblijnych ${ }^{25}$. Najwlaściwszym jednak uważałbym wydanie prac onomastycznych w języku angielskim. W ten sposób znakomity, choć objętościowo niewielki dorobek znakomitego językoznawcy zostałby po raz pierwszy udostępniony i skonfrontowany $z$ osiągnięciami czołowych onomastyków biblijnych. Publikacja taka byłaby nie tylko dobrym wprowadzeniem dla każdego biblisty $w$ rzadko uprawianą dyscyplinę, lecz także holdem oddanym zapoznanemu dorobkowi najwybitniejszego polskiego filologa biblijnego bieżące ‘o stulecia.

Kraków ZDZISEAW J. KAPERA

24 S. Urbańczyk, L'onomastique d'après-guerre à Cracovie, „Onoma" 22, 1978 , s. 753 .

${ }^{25} \mathrm{Z}$ inicjatywa przedruku rozproszonych przekładów fragmentów Biblii wystąpil doc. A. Zaborski na posiedzeniu P.T.T. w dziesiąta roczniç 'śmierci ks. prof. A. Klawka w dn. 22. XI. 1979 r.

Stanisław Rospond

\title{
ONOMASTICA SACRA W NOWYM TESTAMENCIE
}

\section{JEROZOLIMA - JERUZALEM}

O Jeruzalem, Jeruzalem, które zabijasz prorokbw...

(Mt 23, 37: Ek 13, 34)

Onomastyka wspólczesna rozwija się wszechstronnie w obrębie językoznawstwa jako nauka o nazwach własnych i dyscyplina pomostowa; ' lącząc się z archeologią, prehistorią, geografią, topografią, historią osadnictwa, a nawet $\mathrm{z}$ geologią itp. Coraz częściej pojawiają się prace, zwłaszcza w USA, dotyczące tzw. onomastyki literackiej, czyli stylizacji nazewniczej u autorów, którzy posługują się nieraz nazwami wlasnymi znaczącymi (noms - parlants). 
Onomastyka biblijna posiada oczywiscie najdawniejsze zbiory, leksykony i bardzo bogata literaturę. Ks. A. Klawek ', znakomity biblista polski zreferowal stan badan w tym zakresie:

1. Filon Aleksandryjski ( $40 \mathrm{r}$. po $\mathrm{Chr}$.) w ślad za autorami bîblijnymi interpretowal oczywiście pisma biblijne; byly to tzw. etymologie ludowe, alegoryzacyjne -;

2. aleksandryjski autor nieznany opracował po grecku między rokiem 260-290 po Chr. imiona biblijne w NT 3 ;

3. Orygenes († 254), autor „Hexapla" (zachowane fragmenty) 4

4. św. Hieronim, autor Liber interpretationis hebraicorum nominum.

Te oraz jeszcze wiele innych onomastikonow, które przedstawił F. Wutz ${ }^{5}$, oraz P. de Lagarde i i które wyszczególnil ks. A. Klawek dotyczą przeważnie nazewnictwa $\mathrm{Sr}$. Nie ma niestety osobnego opracowania imion NT. Odpowiednie wyjaśnienia podają slowniki greckie do NT W. Bauera ${ }^{7}$ i F. Zorella ${ }^{8}$.

Toponomastyka biblijna doczekała się osobnej monografii w 1930 r. W. Borée ${ }^{9}$.

Również do onomastyki biblijnej, zwłaszcza NT konieczne są nowoczesne kryteria metodologiczne językoznawstwa strukturalnego, mikrofilogicznego i substytucyjnego (od lac. substitutio - rekonstrukcja warstw wielojęzycznych, chronologicznie zazębiających się). W onomastyce biblijnej są one bardzo złożone: np. hebr. Jehoszua -

1 Ks. A. Klawek, Onomastyka biblijna, w: „Onomastica" VII, 1961, S. $403-416$.

2 Por. G. Siegfried, Die hebräischen Worter klärungen des Philo und die Spuren ihrer'Entwicklung auf die Kirchenväter, Magdeburg 1893.

3 Por. Liber interpretationis hebraicorum nominum, w: Patrologia Latina, 23. coll. $771-858$ (św. Hieronim okolo $300 \mathrm{r}$. opracowal w języku lacińskim).

4 F. Field, Originis quae supersunt fragmenta $I$-II, Oxonii $1867-$ 1875 ; B. J. Roberts, The Old Testament text and versions, Cardiff 1951 , s. $128-139$.

5 F. W utz, Onomastica Sacra I-II, Leipzig 1914-1915.

- P. de Lagarde, Onomastica Sacra, Göttingen 1870, wyd. II 1878.

7 W. Ba ue r, Griechisch-deutsches Wörterbuch zu den Schriften des Neuen Testaments und der ibrigen urchristlichen Literatur, 3. wvd. 1937, następne Giessen 1959 r.

8 F. Zore 11, Lexicon graecum Novi Testamenti, Parisiis 1931; por. dobrze opracowane imiona NT w: Ha a g, Bibellexikon, Köln 1951.

9 W. B orée, Die alten Ortsnamen Palaestinas, Leipzig 1930; por. rec. K. Ga 11 ing a, w: "Orientalitische Literaturzeitung" 36, 1933, 239-241. Por. tez A. Jirku, Die ägyptischen Listen palaestinensischer und syrischer Ortsnamen, Leipzig 1937; F.M. A be 1, Géographie de la Palestine II, Paris 1938 , s. $233-490 ;$ T. S im ons, The geographical and topographicai texts of the Old Testament, Leiden 1959; G. Da $1 \mathrm{~m}$ a n, Orte und Wege Jesu, Gütersloh 1924 (toponomastykę NT); W. S z c z e p a ń s k i, Geographia historica Palaestinae antiquae, Roma 1926: t e nże, Mieszkańcy Palestyny pierwotnej (do 1400 r. przed Chr.), Kraków 1920. 
skrócone Joszua, Jeszua = Jahwe wybawia - grec. lesous, lac. Jesus - pol. Jezus.

Do tych dociekań tekstologicznych, kontekstowych powinna nawiązać biblijna onomastyka literacka. Właśnie jeden taki szczegół toponomastyczny z NT stara się autor tego artykulu rozwikłać.

Językoznawca - onomasta nawiązując do tych osiągnięć tejże biblistyki, która od czasów pierwszych Ojców Kościoła aź po dzień dzisiejszy nagromadziła olbrzymią literatur 's jakiej nie posiada żadne inne dzieło, może niejeden szczegół naświetlić od strony nazewniczej.

Jest jeden synonim toponimiczny na oznaczenie miasta świętego, tj. Jerozolimy, niejednokrotnie cytowanej w ST i w NT bądź jako Jeruzalem, bądź Jerozolima:

... nie godzi się, bowiem prorckowi zginąć poza Jerozolima. O Juruzalem, Jeruzalem, które zabijasz proroków i kamieniujesz tych ... (Ek 13, 33-34).

Tuż obok siebie figurujące warianty nazewnicze mają we współczesnym języku polskim odmienne, stylistyczne nacechowanie: dostojna forma Jerúzalem ( $\mathrm{z}$ akcentem na trzeciej od końca zgłosce) oraz potoczna Jerozolima. Por. w poezji Piotra Kochanowskiego w XVII w.:

... powiedz Gofredowi

Czemu próżnuje? czemu tak leniwy?

Niech Jer uzále m nieprzyjacielowi

Por. jeszcze u K. Ujejskiego:

Jeśli ciebie nie ogarnę mym synowskim żalem -

To mnie przeklnij i zapomnij, matko J ér uzálem!

Rzutowanie tych dwu form na tho caloksztaltu zebranych przykladów (oczywiście z oryg. greckiego i innych źródeł ${ }^{10}$ ) umożliwia wyciągnięcie wniosków nieobojętnych dla badań tekstologicznych nad Ewangeliami. Wnioski te dotyczyly:

1. rekonstrukcji tzw. praewangelii w postaci ipsissima verba Jesu $=$ wlasne i na pewno autentyczne słowa samego Jezusa, zachowane w ewangeliach w formie pierwotnej bez późniejszych elementów interpretacyjno-redakcyjnych;

10 Por. W. B a u e r, op. cit., 1937 , s. $619-620$, autor zestawie literature przedmiotowa 0 tych formach 'Ierousalêm, indeclinabile nomen proprium femin, 'Ierosólyma, nomen proprium neutr. plur. oraz femin. sing.; a zatem odsyla do prac o spiritus asper ew. lenis form greckich, konkludujac sceptycznie: „Utber d. Gebrauch d. beiden Namensformen, in deren Anwendungen die Handschriften, selbst schwonken, lässt sich nichts Sicheres ermitteln".

Zależało to jednak, moim zdaniem, od autorów, ich tekstów i materia16w, czyli można znaleźć przykłady sensownie stylistycznie się wyjaśniające i fungujace. Pozornie chaotyczne zestawienie, pêle-mêle nieraz używane układają się funkcjonalnie przy bardziej wnikliwej analizie tekstologicznej. 
2. indywidualnego, osobniczego, stylistycznego nacechowania poszczególnych Ewangelii;

3. wyraźnych podobieństw i różnic między poszczególnymi autorami: 4. konieczności ścislego - wg oryg. greckiego - wyróżniania obu wariantów $w$ tlumaczeniach nie tylko polskich lecz $i$ innojęzycznych. Ciekawe byloijy zestawienie tych wariantów toponomastycznych w tlumaczeniach staropolskich i nowopolskich oraz obcojęzycznych.

Niesłusznie uważano, że nie da się wyciągnąc jakichś sensownych wniosków co do posługiwania się $w$ tekstach ewangelijnych tymi synonimami nazewniczymi.

$\mathrm{Z}$ pełnej dokumentacji, zebranej oczywiście nie $z$ tlumaczeń polskich, lecz $z$ oryginalów greckich $i$ innych źódel, przytaczam tylko w bardzo zwięzlym skrócie najbardziej istotne dane frekwentacyjne: 1. nobliwej formy Jeruzalem użył wyjątkowo w cytacie ewangelijnym (żal Jezusa nad miastem świętym o szczególnym naboju emocjonalnym w charakterystycznym wykrzyknikowym powtórzeniu) św. Mateusz, mając poza tym wylącznie potoczną formę Jerozolima - por. Mt 2,$1 ; 2,3 ; 3,5 ; 15,1 ; 20,17$ (nieściśle tlum. polskie ks. E. Dąbrowskiego podaje Jeruzalem) 21, 1 (tak samo nieściśle Jeruzalem w tymże tlum.); $21,10$.

2. św. Marek i św. Jan poslużyli się w zasadzie formą Jerozolima w odróżnieniu od św. Eukasza, który jako równieź autor Dziejów Apostolskich stosowal formę Jeruzalem: por. Mk 1,$5 ; 3,8 ; 3,22$ (nieściśle thum. polskie Jeruzalem); 7, 1; 11, 1; 11, 11; 11, 15; 11, 27; 15,41 ; por. też $\mathrm{J} 1,19 ; 2,13 ; 2,23 ; 4,20-21$ (w tłum. pol. Jeruzalem oraz $w$ Jerozolimie); 4,$45 ; 5,1 ; 5,2 ; 7,25 ; 10,22 ; 11,18 ; 11,55 ; 12,12$. Natomiast św. Eukasz zastosowal niemal wyłącznie formę Jeruzalen (np. 2, 25; 2, 41; 2, 42; 2, 43; 2, 45 itp. - ogólem 24 razy, a tylko 4 razy Jerozolima: 2,$22 ; 13,22 ; 19,28 ; 23,7$.

$\mathrm{Za}$ jego autorstwem Dziejów Apostolskich przemawia również użycie dominującej formy Jeruzalem (jedynie pod koniec częściej zjawia się Jerozolima).

Należy nadmienić, że wariant Jeruzalem wykazują przedchrześcijańskie źródła biblijne oraz antyczne: grecka Septuaginta, Philo, Josephus Flavius i inni ${ }^{11}$.

Czy i jaka funkcja stylistyczna, a nawet inna wynika z powyźszego frekwentacyjnego stwierdzenia, które można by w rozprawie monograficznej szerzej udokumentować? Co oznacza oponenta, jednorazowa, c y t a c y jn a formula: O! Jeruzalem, Jeruzalem ... u św. Mateusza? Dlaczego św. Eukasz jest pod tym względem odrębny od innych Ewangelistów? Na odwrót św. Marek i św. Jan holdują formie Jerozolima! Oczywiscie należaloby tu jeszcze w specjalnej rozprawie uwzględnić konkordancje $\mathrm{z}$ różnych najwcześniejszych zacho-

11 Por. W. B a uer, op. cit., str. $619-620$. 
wanych kopii ewangelijnych, a to znow dostarczałoby argumentów co do charakterystyki poszczególnych kopii. Zanim na powyższe interesujące pytania odpowiedź znajdziemy, winniśmy zanalizować forma!nie stosunek obu form, przede wszystkim ich związek ściślejszy ew. luźniejszy ze zrekonstruowanym oryginalem przedhebrajskim i późniejszym hebrajskim, z kólei zgrecyzowanym i zlatynizowanym.

Nazwę świętego miasta ludu izraelskiego pisano w języku akkadyjskim urusalim lub urusalimmu, po grecku lerusalém lub Ierusaleme, potem zaś Ierosólyma lub Hierosolyma ( $\mathrm{z}$ tzw. grec. przydechem). W tekście hebrajskim nie wokalizowanym (wcześniejszym), przyjmuje siẹ I-R-SZ-L-M, zaś w wokalizowanym IERUSZALAIM 1:; jest to prawdopodobnie nazwa przedsemicka. Hebrajska etymologia ludowa objaśnia następująco: jeru $=$ miasto, szalem $=$ pokój. Grecyzacja wariantu lerosólyma, jest silniejsza i nowsza, aniżeli lerusalém, które jest bliższe oryginalnemu Jeruszalaim. W obu wariantach zastapicno $s z$ (nieznane grece) przez $s$, ale postać Jerosolyma nawiązuje adideacyjnie do grec. (h/ieros = święty oraz do zakończenia grecyzacyjnego -yma (żaden wyraz grecki nie kończy się na $m$ ).

Poniżsy schemat proweniencyjny i substytucyjny najlepiej to wyjaśni:

(akkadyjskie)

(hebr. nie wokalizowane)

(hebr. wokalizowane)

potem urusalimu, urusalimmu<smiles>C1CCCC1</smiles>

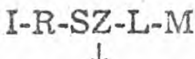

IE-R-Ü-SZ-ÂL-E-M

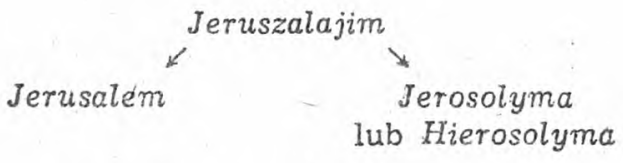

Wariant grecki Jerusalem, ma zaledwie jedną substytucyjną różnicę $\mathrm{w}$ porównaniv $z$ formą hebrajską, îj. $s$ zamiast $s z$; natomiast Jerosolyma i Hierosolyma ma ich znacznie więcej (5); $s$ zamiast $s z$, - zamiast $u$, o zarniast $a$, przydech oraz morfologiczną substytucje w postaci zakończenia -yma.

A zatem a r chaiczna i bliższą oryginalowi hebrajskiemu formą jest grec. Jerusalem, zaś now $\mathrm{sz}$ ą i silnie zgrecyzowaną Jerosolyma! Archaiczne formy językowe cechuje zawsze dostojeństwo i nobliwośc ze względu właśnie na ich autentyzm, który to zostal wiernie przez naocznego świadka czynów Chrystusa (św. Mateusza) w Jego słowach

12 Ks. A. Kla wek, De pronuntatione vocis Jerusalem, "Collectanea Theologica" 1932, str. 384-387; tenże, op., cit., w: "Onomastica" VII, s. 405; S. R os p ond, Mowiq nazwy, Warszawa 1976, str. 183. 
zachowany i respektowany w znamiennym kontekście żalu nad Jeruzalem. Ta opozycja językowa, jednorazowe, cytacyjne z charakterystycznym emocjonalnym repetitio Jeruzalem oraz $\bar{i}$ razy Jerozolima jest bardzo wymowne! Dobrze to też charakteryzuje tego Autora, który jako celnik żydowski najwięcej nawiązuje do ST i jego autentycznych form nazewniczych. Można sobie wyobrazic, jaki byl u niego pietyzm do slynnej swiątyni Salomona i świętego miasta! Dla św. Eukasza charakterystyczny jest też i dlatego ten autentyzrn językowy (Jeruzalem), że - jak charakteryzują Go bibliści - był wykształconym antiocheńskim Grekiem, posługującym się wzorową greczyzną i czerpiącym wiadomości o Chrystusie z ust samej Najświętszej Maryi Panny oraz od Apostoła św. Pawła. Do jego wzorowego i podniosłego stylu należy dodać i tę przeważającą u Niego formę Jeruzalem! Byil to już bowiem nieprzeciętny stylista, świadomie respektujący autentyczną i nobliwą formę Jerusalem.

Należy nadmienić, że w Antiquitates iudaicae Józefa Flawiusza (100 r. po Chr.) ${ }^{13}$, są nazwy biblijne zgrecyzowane: Abraham Abramos, Noe - Nochos, Jonatan - Ionathes, również Jerusalem Hierosolyma.

Literacka onomastyka, o której wzmiankowalem na początku artykułu jako dziele bardzo szeroko pojętej nauki o nomina propria, odkrywa złoża nazewnicze, osobnicze, stylistyczne właściwości autora tekstu, oryginalu a kopii itp Próbę jej praktycznego zastosowania dla onomastica sacra przedstawiłem na przykładzie dubletów (oczywiście greckich) Jerusalem - Jerosolyma (Hierosolyma).

Wroclaw

STANISEAW ROSPOND

13 Por. H.S. Thackeray, Josepinus, the Man and the Historian, New-York 1929; A. Schlatter, Die hebräischen Namen bei Josephus, Güitersloh 1913.

\section{Ks. Jerzy Chmiel}

\section{BADANIA ONOMASTYCZNE W EGZEGEZIE BIBLIJNE]}

Celem niniejszego krótkiego szkicu jest syntetyczne przedstawienie rozwoju badań onomastycznych - prowadzonych dla egzegezy tekstów Pisma Swiętego; chodzić tu będzie nie tyle o aspekt lingwistyczny, ile raczej i przede wszystkim o aspekt biblijny.

W rozwoju badań onomastycznych możemy wyróżnić kilka etapów.

Najstarszy etap ma riiejsce w samym Piśmie Sw., gdzie występują interpretacje imion hebrajskich wedlug zasad etymologii popularnej, czego przykładem jest $\mathrm{Rdz} 29-30$ odnośnie do imion synów Jakuba. 